Helgoländer wiss. Meeresunters. 20, 637-641 (1970)

\title{
Management of closed-system marine aquariums
}

\author{
V. C. Goldizen \\ Aquarium Systems, Inc.; Wickliffe, Obio, USA
}

\begin{abstract}
KURZFASSUNG: Betrieb geschlossener Meeresaquariensysteme. In geschlossenen Meerwassersystemen, die mit marinen Tieren besetzt sind, verringern sich die Alkali-Reserve, der $\mathrm{pH}-$ Wert und der $\mathrm{O}_{2}$-Gehalt, während die Konzentration anorganischer Stickstoffverbindungen, des $\mathrm{CO}_{2}$, der Phosphate, der gelösten organischen Substanzen und der Bakterien zunimmt. Es wurde daher eine Konstruktion für ein einfaches rezirkulierendes Meerwassersystem entwickelt, das diese Veränderungen der Wasserqualität verringert und einen guten Zustand gehälteter Meerestiere gewährleistet. Dieses System wird in seinem Aufbau beschrieben. Die gewonnenen Erfahrungen haben gezeigt, daß ein Wasservolumen von 5001 und eine Wasserfiltration von $80 \mathrm{l} / \mathrm{m}^{2} / \mathrm{min}$ bei einem Filterbrett von $0,1 \mathrm{~m}^{3}$ (bestehend aus einer 2-5 mm dicken Schicht Mghaltigem $\mathrm{CaCO}_{3}$ ) für $1 \mathrm{~kg}$ Octopus bimaculatus, $5 \mathrm{~kg}$ Strongylocentrotus purpuratus oder $7 \mathrm{~kg}$ Homarus vulgaris zugrunde gelegt werden kann.
\end{abstract}

\section{INTRODUCTION}

Cultivation of marine organisms in recirculating systems confers upon the investigator independence from variations in salinity, temperature, turbidity, plankton blooms and increasing levels of pollution occurring in the near-shore environment from which sea water supplies are usually drawn. An increasing number of laboratories have found it necessary to construct closed - or more correctly semi-closed systems, as some replacement of the culture medium is necessary. The development of artificial sea waters now allows biologists to work with marine organisms inland throughout the year, but the cost of these synthetic media requires that the solutions be retained in use as long as possible. It is in these inland areas that semi-closed systems are mandatory, but the degree of environmental control attainable is also of interest to the investigator in a laboratory supplied with running natural sea water. However, chemical changes can be detected in a captive volume of sea water within minutes after its removal from the sea (Collier \& MARvin 1953), and rapid changes can also be detected in completely artificial systems after the introduction of living organisms. These alterations are the result of the metabolic activities of all the organisms present in the system and lead in time to a diminished capacity of the medium for supporting life. ATz (1964) reviewed and summarized the major changes as decreases in alkaline reserve, $\mathrm{pH}$, and oxygen content concurrently with increases in the concentrations of inorganic nitrogen compounds, carbon dioxide, phosphates, dissolved organic compounds and bacteria. Of these, loss of alkaline reserve, increase in 
ammonia concentration, and decrease in oxygen content are the factors which first become critical.

\section{WATER MANAGEMENT TECHNIQUES}

Replenishment of alkaline reserve can be achieved by the use of chemical buffers; the most applicable of these is based on carbonates and is related to the equilibrium in the sea:

$$
\mathrm{CO}_{2}+\mathrm{H}_{2} \mathrm{O} \rightleftharpoons \mathrm{H}_{2} \mathrm{CO}_{3} \rightleftharpoons \mathrm{HCO}_{3}-+\mathrm{H}^{+} \rightleftharpoons \mathrm{CO}_{3}^{2}-+\mathrm{H}^{+}
$$

Pure calcium carbonate (calcite) is not readily soluble at the $\mathrm{pH}$ of sea water, but natural calcium carbonates containing a minimum of $4 \%$ magnesium, e.g. dolomite, coral gravel and mollusc shells, contain solubility sites which promote solution of the buffer in the presence of hydrogen ions. A high rate of gas exchange with the atmosphere, achieved by diffusing air into the system, will remove much of the free carbon dioxide and aid in shifting the above equation to the left while insuring that dissolved oxygen is at near-saturation levels.

In a system containing large surfaces for bacterial attachment, for example a filter bed composed of sand or calcareous gravel, inorganic nitrogen appears first as ammonium ion, then nitrite, and finally as nitrate. This is a function of the nitrifying sequence involving two types of chemoautotrophic bacteria and results in the accumulation of nitrate ions under aerobic conditions. Nitrate is considerably less toxic than the first two inorganic nitrogen forms, but high concentrations do appear to interfere with respiration (HrRAYAMA 1966c).

Some direct oxidation of ammonia to nitrate can be achieved by ozonation, but extreme care must be taken to prevent excess ozone from entering the laboratory and affecting both personnel and materials present. Ion-exchanging resins have been used for the removal of nitrates, but do not appear to be sufficiently selective at this time to avoid inducing imbalances in other ions. Nitrate removal is most simply achieved by replacing portions of the sea water; this procedure also dilutes other metabolites and replenishes trace elements taken up by organisms.

A useful device for removing dissolved proteins and amino acids before they are bacterially altered to produce ammonia involves producing a large volume of fine air bubbles bearing electrostatic charges. Amphoteric molecules are attracted to the bubbles to produce a foam which can be skimmed off the surface of the water and discarded at the expense of loss of iodine and some trace metals. Particulate materials are carried off in the foam, but carbohydrates and lipids are not efficiently removed by this device.

Suspended bacterial populations will remain minimal if the system is not overcrowded and the animals are not overfed. Means of reducing the numbers of bacteria, if this should be required, include microfiltration, ozonation, and the application of ultraviolet light to thin films of water (Herald et al. 1962). It should be noted, however, that none of these techniques results in a totally sterile environment, as organisms contained in the system are themselves sources of microorganisms. Antibiotics have found wide application in larval culture, but we know of no instance in which large numbers of adult organisms are maintained in the presence of antibiotics. 
Phosphate levels found in semi-closed systems are not known to be toxic to the contained organisms if the system contains a calcareous filter bed, as the phosphate is precipitated as the calcium salt. This process can occlude buffering surfaces, necessitating stirring of the filter bed at intervals.

Dissolved organic compounds include both those simple molecules which can be directly absorbed and utilized by many organisms (STEPHENS 1968) and a wide variety of compounds whose effects are, as yet, not well known or are undescribed. Among these are pigmented complexes similar to the "Gelbstoff" described by KaLLE (1966) in the North Sea. Organic complexes may be removed on adsorbents such as activated charcoal, or held at low levels by dilution.

\section{BASIC DESIGN PARAMETERS}

In an effort to produce a culture system of simple design and having low maintenance requirements, and yet be capable of culturing or holding a wide variety of marine organisms for research or teaching purpose, the configurations proposed by SAEKI (1958) and Kelley (1963) have been modified. The extensive work of HiraYAMA (1965a, b, 1966a, b) on filter bed configurations using the Japanese sea bream Chrysopbrys major as the test animal has been found to be effective for fishes and correlates well with the following criteria based on the culture of a delicate animal, Octopus bimaculatus: (1) 5001 of medium per $\mathrm{kg}$ of animal. (2) A $0.1 \mathrm{~m}^{3}$ filter bed consisting of 2-5 mm grains of a magnesium-containing calcareous filtrant. (3) A flow rate of 801 per $\mathrm{m}^{2}$ of filter bed surface area per min. (4) Replacement of $25 \%$ of the culture medium per month. Systems of similar design will maintain $5 \mathrm{~kg}$ of the sea urchin Strongylocentrotus purpuratus or $7 \mathrm{~kg}$ of the American lobster Homarus americanus.

Temperature control is provided where necessary, and all components of the systems are individually checked for toxicity according to the recommendations of BERNHARD et al. 1966), who assayed inhibition of development of the larvae of the sea urchin Arbacia lixula after exposure to the materials to be tested. We employ the Pacific Coast sea urchins Strongylocentrotus purpuratus and Lytechinus pictus in similar tests, and exclude any metals from direct contact with the culture medium.

\section{DISCUSSION}

The criteria described have been successfully applied to systems ranging in capacity from 80 to 300,000 liters and containing animals as diverse as the sponge Microciona prolifera and the dolphin Tursiops truncatus. Because of this diversity in application and the mixed populations frequently held in the systems, maintenance has been restricted to feeding the animals and replacing a portion of the culture medium at intervals. The latter procedure has been found to be the simplest and least expensive means of controlling many of the changes taking place in the medium, while allowing the development of an in situ plankton as a food source for filterfeeding organisms. 
Modifications for special culture applications have included the addition of adsorbent filters, ozone generators, and ultraviolet light sources.

\section{SUMMARY}

1. The major changes which take place in a captive body of sea water include decreases in alkaline reserve, $\mathrm{pH}$, and dissolved oxygen. Inorganic nitrogen compounds, carbon dioxide, phosphates, dissolved organic compounds and bacteria increase in concentration.

2. Methods which have been applied to reduce the rates of these changes in semiclosed systems include buffers, nitrification by bacteria, ozonation, ion-exchange resins, protein foaming, ultraviolet light, microfiltration and dilution of the culture medium.

3. Design criteria for a basic culture system include, for Octopus bimaculatus: (a) 500 liters of medium per $\mathrm{kg}$ of animal; (b) a $0.1 \mathrm{~m}^{3}$ filter bed consisting of $2-5 \mathrm{~mm}$ grains of magnesium - bearing calcium carbonate; (c) a flow rate of 801 per $\mathrm{m}^{2}$ of filter bed per min; and (d) replacement of $25 \%$ of the culture medium per month.

4. Similar systems will support heavier loads of hardier animals, e.g. up to $7 \mathrm{~kg}$ of Homarus americanus.

\section{LITERATURE CITED}

ATZ, J. W., 1964. Some principles and practices of water management for marine aquariums. In: Sea-water systems for experimental aquariums. Ed. by J. R. \& R. L. Clark. Res. Rep. U. S. Fish Wildl. Serv. 63, 3-16.

Bernhard, M., Zattera, A. \& Filest, P., 1966. Suitability of various substances for use in the culture of marine organisms. Pubbl. Staz. zool. Napoli 35, 89-104.

Collier, W. \& Marvin, T., 1953. Stabilization of the phosphate ratio of sea water by freezing. Fishery Bull. U. S. Fish Wildl. Serv. 54 (79), 69-76.

Herald, E. S., Dempster, R. P., Wolters, C. \& Hunt, M. L., 1962. Filtration and ultraviolet sterilization of sea water in large closed and semi-closed aquarium systems. In: Communications. 1er Congrès International d'Aquariologie, Monaco 1960. Bull. Inst. océanogr. Monaco No spécial 1B, 49-62.

Hirayama, K., 1965a. Studies on water control by filtration through sand bed in a marine aquarium with closed circulating system. I. Oxygen consumption during filtration as an index in evaluating the degree of purification of breeding water. Bull. Jap. Soc. scient. Fish. 31, 977-982.

- 1965b. Studies on water control... II. Relation of filtering velocity and depth of sand layer to purification of breeding water. Bull. Jap. Soc. scient. Fish. 31, 983-990.

- 1966a. Studies on water control ... III. Relation of grain size of filter sand to purification of breeding water. Bull. Jap. Soc. scient. Fish. 32, 11-19.

- 1966b. Studies on water control ... IV. Rate of pollution of water by fish and the possible number and weight of fish kept in an aquarium. Bull. Jap. Soc. scient. Fish. 32, 20-27.

- 1966c. Influence of nitrate accumulated in culturing water on Octopus vulgaris. Bull. Jap. Soc. scient. Fish. 32, 105-111.

Kalle, K., 1966. The problem of the Gelbstoff in the sea. Oceanogr. mar. Biol. A. Rev. 4, 91-104. 
KeLLeY, W. E., 1963. Ideal configuration for a semiclosed circulating aquarium system. In: Program. 50th anniversary meeting of the American Society of Ichthyology and Herpetology, Vancouver, Can.

SAEKI, A., 1958. Studies on fish culture in filtered closed-circulation aquaria. Fundamental theory and system design standards. Bull. Jap. Soc. scient. Fish. 23, 684-695.

StEPHENS, G. C., 1968. Dissolved organic matter as a potential source of nutrition for marine organisms. Am. Zool. 8, 95-106.

Author's address: V. C. Goloizen

Aquatic Sciences, Inc.

Boca Raton, Fla., USA 